Jagor Bučan

UDC 75.01

Sveučilište u Zagrebu

doi:10.5937/ZbAkUm1705043B

Akademija likovnih umjetnosti

Hrvatska

\title{
Topos neizrecivog:
}

\section{Prilog temeljnim pretpostavkama odnosa slike i jezika}

Apstrakt: Ogledom se razmatraju neke od osnovnih pretpostavki razumijevanja slikarskog djela. Prva među njima je fizička razdvojenost djela i promatrača. Ona u doživljajnom smislu otežava, ali u spoznajnom smislu olakšava pristup slici. Razdvojenost u nama proizvodi čuvstvo fascinacije, koje čuvstvo povratno projiciramo u sliku, čime ona za nas postaje predmet žudnje. S estetskog motrišta posljedica te projekcije je osobit vid lijepog, kojivid posjeduje utopijski potencijal. Utopija kao Ne-mjesto drugi je pojam za ono što u slici možemo nazvati neizrecivim. Utopija nije ikonografska sastavnica, već ontološko svojstvo slike - slika je uvijek nedostižna, nedohvatna, budući da je tek (tvarna) utvara. Njena samobitnost očituje se u fenomenu cjeline. On se pak u slici očituje kao koherencija, podudarnost i imitacija. Međutim, fenomen cjeline uvijek nam spoznajno izmiče, što sliku čini uzbudljivom i zagonetnom pojavom koja plijeni našu pažnju, uvijek nanovo u nama proizvodeći spoznajnu žudnju. Ključne riječi: slika, fascinacija, utopija, lijepo, cjelina

\section{Fascinacija kao simptom nedohvatnog}

„Vidjeti pretpostavlja udaljenost, razdvajajuću odlučnost, moć da se ne bude u kontaktu i da se u kontaktu izbjegne pomutnja. Vidjeti znači da je to razdvajanje ipak postalo susret.“" (Blanšo, 2015: 23)

U obrisu općenitog pristupa, iskustvo slikarskog djela, u odnosu spram književnog ili, pak, glazbenog djela, obilježeno je osebujnom prijemčivošću. Glazba slušatelja akustički obuhvaća i vibracijski prožima. Ne pruža mu podršku narativnog ili simboličkog posredništva, već ga izravno dotiče svojim frekvencijskim ticalima. Slušatelj je izručen glazbenom doživljaju čitavim svojim bićem, uključujući i tjelesni aspekt, onaj dio njega koji i sam zvuči, koji pulsira krvotokom i koji makinalno motorički odgovara na glazbeni poticaj, tapkajući, njišući se ili plešući. Čitatelj pak ima rijetku privilegiju identifikacije. Narativnim umijećem pripovijedača kojemu se svojevoljno 
prepustio, on postepeno biva uvučen u razvojni tijek romana, poistovjećujući se $s$ likovima koje prati u dramaturškom izlaganju. Štoviše, stvaranjem slika na unutarnjem ekranu imaginacije on reagira na pišćeve poticaje i na taj način posvaja štivo na vlastiti, neponovljiv i jedinstven način. Tako, jednako kao slušatelj ili plesač, postaje izravnim dionikom umjetničkog djela; postaje subjektom komunikacijske razmjene. Razmjena je ta koja je uvjet samog književnog djela; djelo jest samo onda (prema Morisu Blanšou /Maurice Blanchot/) kada se ostvaruje kao intiman odnos između autora i njegova čitatelja. Doživljaj slikarskog djela u bitnome je drugačiji. Promatrač pred slikarskim djelom nije ništa manje subjektom, on uzvraća na slikovne poticaje perceptivno, emotivno i misaono. No, za razliku od čitatelja i slušatelja, između njega i predmeta njegova interesa postoji jaz. Jaz je uostalom i osnovni fizički preduvjet motrenja slike da bi slika bila opaženom, motritelj mora biti na primjerenoj udaljenosti. ${ }^{1}$

Ta elementarna činjenica može se učiniti odveć banalnom i doslovnom. No, ukoliko je prihvatimo in nuce, u njenom zametku možemo uočiti mogućnost transpozicije koja nam otvara pristup razumijevanju naravi slike. Štoviše, nećemo pretjerati ako kažemo da je upravo premoštenje toga jaza osnovna pretpostavka za svaku interpretaciju slike, osobito za onu koja nastoji sagledati odnos slike i jezika. Jaz nas na pukoj fizičkoj razini razdvaja od slike kao objekta. Ali istodobno, na spoznajnoj razini jaz omogućuje primicanje uvidu. Jaz, dakle, istodobno razdvaja i spaja, ovisno o razini pristupa. Zbližavanje uvidom kao posljedicom (afektivnog) odmaka vrijedi i za spomenute discipline. Kognitivne reakcije pri slušanju i čitanju traže od nas doživljajni odmak da bismo bili u mogućnosti refleksivno reagirati. Upravo odmak omogućuje da glazbeno, odnosno književno djelo sagledamo u prespektivi različitih motrišta. Na taj način se prvotni doživljaj obogaćuje, rafinira i potom integrira u naše cjelovito iskustvo. Zato je preporučeno slušati glazbeno djelo s partiturom u rukama, ne bi li upravo vizualna provjera notnoga zapisa našoj pažnji pružila pouzdani (afekata lišen) oslonac pri slušnom praćenju skladbe. S druge strane, načitani ljubitelj književnosti kadar je potisnuti primarni identifikacijski refleks, odnosno uzdići ga na razinu poredbenog odmaka pri sagledavanju književnog umijeća kao takvog (također lišenog afektivnih primjesa).

I slikarskom djelu, dakle, ponekad valja prići nezainteresirano (neintencionalno), da bi smo se tako otvorili za sve ono što nam slika nagoviješta s onu stranu čulnih obećanja. Međutim, fizički razmak koji dijeli sliku od njene publike začudo nema ulogu afektivnog osigurača. On, naprotiv, pokreće čuvstvo koje paletom varijanti prati 1 Izlišno je navoditi rijetke primjere koji tome proturjeèe, poput sluèaja Barneta Njumena (Barnett Newman) koji je od gledatelja tražio da njegove slike monumentalnih dimenzija i all over monohromnih ispuna gleda posve izbliza, ne bi li slika posve ispunila njegovo opažajno polje. Razlog je bio opravdan - Njumen je na taj naèin pojedincu jamèio doživljaj prisutnosti „sada i ovdje“, osigurao mu je doživljaj potvrde dragocjene spoznaje: ja jesam. 
naš doživljaj slike. To čuvstvo ima generativnu vrijednost, što će reći da ima funkciju zamašnjaka koji u gledatelja pokreće čitav niz reakcija. Stoga ga možemo shvatiti kao svojevrsni lakmus koji reagira na bitna obilježja slike, upućujući nas na njeno razumijevanje. (Ovaj put nije riječ o razumijevanju proizašlome iz trijeznoga odmaka, već o iskustvu doživljajnog primaka koji tek posljedično možemo razmatrati trijezno. Tek nakon što smo se dragovoljno izručili njegovu utjecaju.) Riječ je o čuvstvu fascinacije koje doživljaju slikarstva daje osebujnu aromu i koje možemo uzeti kao polazišnu osnovu za prikazivanje onog aspekta slikovnog koji izmiče pokušaju da slikarsko djelo sagledamo s poredbenih pozicija jezika.

Intencionalni pristup slici nećemo moći usvojiti kao jednoznačan. Doživljaj fascinacije slikom kao osobitom stvarju uvjetovan je osjećajnim primakom. No, upravo smo ustvrdili da to čuvstvo doživljavamo pod pretpostavkom razdvojenosti. Na koji način je to proturječje moguće pomiriti? Tako što ćemo, kao što smo već rekli, razlikovati razine u pristupu; razdvojiti ćemo fizičku razinu od spoznajne. Ono što na fizičkoj razini razdvaja, na spoznajnoj spaja. No, ujedno ćemo vidjeti da se te dvije razine preklapaju i prožimaju. Naime, dok ih je moguće bez poteškoće razlučiti u teoriji, praktično iskustvo nam govori da se one javljaju istodobno kao paradoksalna proturječja. Da bismo predloženu dihotomiju intencionalno/neintencionalno mogli svrsishodno usvojiti, moramo se suočiti s tim proturječjem i nastojati ga pobliže razmotriti.

Slike na stanoviti način iznevjeruju naša očekivanja. Ukoliko ih u ključu renesansne paradigme poimamo kao prozor u svijet, tada nas zavodljive slike redovito ostavljaju na cjedilu. Nikada nećemo moći, za razliku od slikara Vang-Foa (WangFo) (Jursenar/Yourcenar, 1999: 9-19), doista ući u sliku koja svojim iluzionističkim čarima imitira stvarnost, ili je pak nadomješta idealiziranom verzijom. Ako je, s druge strane, promatramo kao konkretnu, apstraktnu činjenicu lišenu mimetičke iluzije, tada naša čulna opijenost njome također ostaje neiživljenom. Fascinaciju slikom ne možemo kanalizirati fizičkim posjedovanjem, poput plesača koji zaposijeda glazbu pokretima svojega tijela (ili kojega je, pak, glazba zaposjela navodeći ga na ritmičko gibanje). Slika gledatelja ostavlja osujećenim. Obraća se samo osjetu vida; haptički doživljaj njene površine irelevantan je za doživljaj likovne strukture. Sliku možemo jedino kontemplirati, motriti s distance, čime polovica našeg bića ostaje zakinutom. ${ }^{2}$ Fascinacija kojom slika djeluje na nas proizlazi upravo iz te zakinutosti, nemogućnosti da se opazi i dohvati stvaran predmet, da se Parazijeva (Parrhasius)zavjesa doista ukloni s predmeta žudnje.

2 Prisjetimo se prispodobe iz Mundaka Upanišadeo dvije ptice koje sjede na grani - jedna jede plod, druga ga samo motri. Te su dvije ptice prema uvriježenim tumaèenjima dva dijela naše duše (Mundaka Upanišada 3.1.1; Svetasvataria Upanišada 4.6; najstarija potvrda je u Rksamhiti Upanišadi 1.164,2). 
„Za svakoga tko je fasciniran možemo reći da ne zapaža nijedan stvaran predmet, nijedan realan oblik budući da ono što vidi ne pripada svijetu stvarnosti nego neodređenom mjestu fascinacije.“(Blanšo, 2015: 24)

U glasovitom ogledu o poetici književnog stvaranja, Blanšo posvećuje fenomenu slike kratak i pronicljiv odjeljak. Raspravljajući o spisateljskom umijeću sa stanovišta temeljnih postulata, on ističe upravo fascinaciju kao rezultat razdvajanja. Znakovito je da to čuvstvo opisuje, služeći se fenomenom slike. Za njega, mjesto fascinacije je apsolutno. Ono se podudara s perceptivnom udaljenošću onog što je slikom prikazano, udaljenošću koja je „prekomjerna“: „Ona je bezgranična i beživotna dubina iza slike kojom se ne može upravljati i koja je apsolutno prisutna premda nije dana"(Blanšo, 2015: 24). Sklon posezanju za paradoksom kada govori o slici (jednako kao i o literarnim djelima), Blanšo neizravno ukazuje na njenu bitnu odliku: ona vidljivim čini ono bezgranično i nedohvatno. Biranim riječima koje odlikuje pojmovna istančanost, on uspijeva izraziti pojavu koja u sebi spreže opreke, doživljaj koji svojstvo ambigviteta sagledava kao karakterističnu odliku slikovnog. Ta odlika fenomen je koji suštinski leži iza riječi. Da bi se taj fenomen prikazao u jeziku, potrebno ga je propustiti kroz filter paradoksa; učiniti da se poklapanjem oprečnosti ono slikovno pokaže u svojoj biti.

Slikom prikazano - kako nadalje zapaža Blanšo - biva na stanoviti način „urušeno u sebe sâmo“, čime se ujedno otuđuje od vlastita smisla ,propadajući u vlastitu sliku“. U tom iskazu možemo prepoznati ikonoklastički temperament koji se provlači kroz Blanšoova rezoniranja. Djelo nije kadro izraziti ništa drugo doli činjenice da jest. Ta tvrdnja u dosluhu je s ozloglašenom izjavom Stravinskog koji je glazbenom djelu također zanijekao mogućnost izražavanja bilo čega njemu izvanjskoga (Stravinski, 1975: 53). Blanšoova tvrdnja je radikalnija, budući da njene implikacije stavljaju ad acta posrednički aspekt slike. Slikarska djela imaju mogućnost posredovanja sadržaja koji im je izvanjski. Ona operiraju prikazima, imaginarnim ili stvarnim. Slika i nije drugo do li prikaz, nešto što se prikazuje, neovisno o naravi prikazbenog sadržaja. No, značenjski udio tih prikaza je ograničen. Ti se prikazi - ili radije: te prïkaze ${ }^{3}-$ posljedično raspršuju, „urušavaju se“ u sebe sâme. Odnosno, kažimo tako, urušavaju se u procjep nedohvata. „Slika se nikad ne može dosegnuti, budući da je slika“(Blanšo, 2015: 85). Predmetnost slikarskog djela je irelevantna s tog motrišta, čak i u slučaju onih slikâ koje tematiziraju vlastite materijalne sastavnice ili u sebe uključuju strane materijale i predmete (brikolaž, dekolaž, asemblaž, djela informela $\mathrm{i}$ arte povera, itd.). Takvi primjeri eventualno proširuju perceptivni, kao i značenjski obuhvat, ali ne utječu u bitnome na slikovnu narav. ${ }^{4}$ Zato se s pravom može kazati da slika počiva na 3 Priviđenje, utvara, slika čega, prikazanje.

4 Izuzev sluèajeva u kojih prevagom udjela stranih sastavnica unutar slike dolazi do preobrazbe slike u objekt, odnosno instalaciju. Paradigmatski primjer djelo je Frenka Stele (Frank Stella) u svojem hronološkom razvoju. 
nestalnom, nedohvatnom mjestu ispred, odnosno iza svoje postojane fizičke pojavnosti. Ta se činjenica može iskazati jedino oksimoronom: slika je tvarna utvara; pojava koja posjeduje egzistenciju što se proteže izvan vlastitih fizičkih datosti, pojava kojoj je postojanje časovito i krhko, podložno mijeni.

Ovdje nas ne zanima subverzivni potencijal koji je diskretno prisutan u naravi slikovnog i koji se očituje kao proturječje u strategijama prikazivanja. Zanima nas upravo taj čin urušavanja i rascjep koji guta krhke prïkaze. Stoga je važno istaknuti da je jaz kojim slika privlači gledatelja, držeći ga ujedno na razdaljini, istinska mjera onog u slici vidljivoga. Vidljivoga koje površinu slike čini predočivom, stavljajući je istovremeno u perspektivu nedohvata. U slikarstvu taj nagovještaj privlači upravo nemogućnošću svoje realizacije. Zato učinak fascinacije slikom možemo sagledati u svjetlu zavođenja kojim nas slike mâme. Pojmovne opreke, paradoksalne protimbe, vjerno predočavaju njihove čìni:

„Tkogod je fasciniran zapravo ne vidi ono što vidi već ga to dotiče neposrednom bliskošću, hvata ga i privlači, u potpunosti ga ostavljajući na udaljenosti."(Blanšo, 2015: 25)

\section{Utopijski potencijal lijepog}

Strategije zavođenja kojom slikarska djela salijeću namjernike nisu bez posljedica; one žigošu osebujnim biljegom. Razapet između neposrednog inedohvatnog, vabljen nagovještenom bliskošću koja istodobno neočekivano uzmiče, gledatelj biva obilježen čuvstvom kojeg možemo shvatiti kao narednu deklinaciju doživljaja fascinacije. O čemu je riječ? O osjećaju koji svaki ljubitelj slikarstva poznaje kao notu sjete što poput istančanog bouqueta prati vizualni doživljaj slike. Taj karakterističan učinak ima estetičku potku - on je spregnut s doživljajem lijepog. Doživljaj lijepog, posredovan slikama u nama, začinje emociju bolećivog nagnuća. Riječ je o emociji koja proizlazi iz osjećaja naše naravne zakinutosti za egzistencijalno dioništvo u ljepoti. Kao što fascinacija dolazi u paru s istodobnom bliskošću/udaljenošću slikom prikazanog, tako je i sjeta bolećivo čuvstvo spareno s nedokučivošću lijepog. Sjeta se pak u sljedećoj deklinaciji sklanja melankolijom, čuvstvom koje je Po držao povlaštenim izričajem ljepote i kao takvim jedinim zakonitim područjem poezije:

„Ljepota je jedino zakonito područje poezije. Najintenzivniji, najuzvišeniji inajčišći užitak kontemplacijeje ljepota.A ton njezine najviše manifestacije ton je tuge. Ma kakva ljepota bila, ona do suza dira osjetljivu dušu. Stoga legitimni ton poezije može biti samo melankolija.“(Po, 1986: 255) 
Zakoniti brak između poezije i melankolije nije slučajno blagoslovio jedan od prvosvećenika dekadencije. Izravno potomstvo te sveze obilježilo je epohu fin de sièclea i tako kultiviralo ozračje koje je proželo posve različite autorske senzibilitete dvadesetog i našeg stoljeća, kako unutar književnog stvaralaštva, ${ }^{5}$ tako i unutar slikarskog. ${ }^{6}$ Ukratko, riječ je o karakteristici koja pripada osebujnom razdoblju, specifičnim poetikama. Bilo bi neprimjereno to obilježje izdvojiti i istaknuti kao prevladavajuću estetičku oznaku koju bismo uzeli za paradigmu našeg odnosa spram slike. Stoga, kada to ipak činimo, kada pojedinačno historijsko i poetičko obilježje transponiramo kao općenitu ahistorijsku značajku, tada smo o tomu dužni položiti račune. To se ne odnosi samo na duševno čuvstvo (ili pak duhovno stanje) koje smo u par navedenih inačica apostrofirali, već i na sam pojam lijepog.

Danas je za mnoge anakrono isticati ljepotu kao odliku umjetnine, čak i u onih djela koja su u svoje vrijeme programatski sačinjavane da bi bile „naslonjačem za oko“. Ljepota je odavno prevladana kao utopijski surogat, osobito tamo gdje je nastojala afirmirati pojam istine u vidu potencijalnog estetskog nacrta. ${ }^{7}$ No, čak i negacija lijepog nerijetko ima utopijski potencijal. Adorno je, zagovarajući negativan stav kojim umjetnina treba odražavati sveprisutni nesklad svijeta, ustvrdio reciprocitet na kojem počiva mogućnost utopije:

„Samo apsolutnim negativitetom umetnost izriče ono neizrecivo, utopiju.“ (Adorno, 1979: 211)(istaknuo J. B.)

Neovisno o tomu je li imala pozitivan ili negativan predznak sa stanovišta poimanja lijepog, slika je često vršila ulogu utopijske tvorevine. Možemo se stoga prikloniti Adornovu prijedlogu i pojam utopije uzeti kao jedan od sinonima za neizrecivo. Ukoliko smjeramo k razumijevanju neizrecive naravi slikarskog djela (koja narav za doživljajnu podlogu ima navedena čuvstva), utoliko nam je potrebno (re)afirmirati i pojam utopije kao osobitog vida umjetnički lijepog. Zato ćemo pojam neizrecivog združiti s pojmom utopije, razumijevajući je kao pokušaj dohvata onog nedostižnog. Pri tomu, slikovni

5 Žoris-Karl Uismons (Joris-Karl Huysmans), Andrej Beli (Andrei Bely), Virdžinija Vulf (Wirginia Wolf), Franc Kafka (Franz Kafka), Herman Broh (Hermann Broch), Dino Bucati (Dino Buzzati), Šandor Maraj (Sándor Márai), Milan Kundera (Milan Kundera), Tomas Bernhard (Thomas Bernhard) i dr.

6 Odilon Redon (Odilon Redon), Wilhelm Hameršoi (Vilhelm Hammershøi), Pjer Bonar (Pierre Bonnard), Đorðo de Kiriko (Giorgio de Chirico), Paul Kle (Paul Klee), Rene Magrit (René Magritte), Đorðo Morandi (Giorgio Morandi), Edvard Huper (Edward Hooper), Vols (Wols), Mark Rotko (Mark Rothko), Anselm Kifer (Anselm Kiefer), Gerhard Rihter (Gerhard Richter), Lik Tojmans (Luc Tuymans), Majkl van Ofen (Michael van Ofen) i dr.

7 ,Ja Vam dugujem istinu u slikarstvu i ja ću Vam je reći.“ Pol Sezan (Paul Cézanne, u pismu Emilu Bernaru (Émile Bernard), 23. Listopada 1905. (citirano u Derida, 1988: 6) To Sezanovo (neispunjeno) obećanje ideološki je opteretilo slikarove slijednike; postalo je estetski i etički imperativ kojemu su se pojedinci poput Lea Juneka dragovoljno predali, posvetivši svoja slikarska nastojanja ostvarenju tog imperativa. 
iskaz utopijskog Ne-mjesta nećemo sagledati kao ikonografsku činjenicu, već kao perceptivni simptom nedohvata; ne kao prikaz, nego kao opaženo mjesto koje redovito izmiče pokušaju da mu se približimo, da ga zaposjednemo.

Utopijski vid slike nije, dakle, slikovna rekonstrukcija arkadije; nije ono što vidimo na djelima čeznutljivih engleskih prerafaelita ili egzotici sklonih francuskih orijentalista. Nisu to niti tzv. ,antislike“, ili pak ,posljednje slike“ poput onih Eda Rajnharta (Ad Reinhardt), koji je programatskim negativitetom svojeg poetičkog postupka ostvario slikovni ekvivalent navedene Adornove preporuke. Naprotiv, utopijske slike sva su ona djela koja su svoje dostojanstvo izgradila na mjeri vlastite samobitnosti. To se dakako odnosi i na Rajnhartova djela, ali ne zbog njihovog formalističkog nijekanja, ${ }^{8}$ već upravo zbog njihove toliko razvidne samosvojnosti. Dostojanstvo slike odnosi se na slike koje su to odista. Na sliku koja jest. Jer, biti odista u varljivom svijetu, za pojedinca je teško dosežan imperativ. Slika kao utopija smjera kompenzaciji tog egzistencijalnog prohtjeva. Ona pruža privid koji prihvaćamo kao vid, kao odliku. Na ovomu mjestu nije prigodno raspravljati o tomu koja i kakva bi to bila odlika istinskog bivanja, ukoliko je takav imperativ za nas uopće važeća kategorija. No, što bi to bilo „biti odista“ kada je riječ o slikama? Što razumijevamo pod samobitnošću djela? U kakvom su odnosu konkretna, ostvarena slika i utopija kao idealno stanje koje nije ostvarivo? Oni su u odnosu supstitucije koja umjetninu poima kao svojevrsni nadomjestak zbilje, pokušaj ostvarenja djela koje ne bi bilo puko podražavanje stvarnosti, već njena kvalitativna istoznačnica. Utoliko se samobitno djelo ne povodi za kakvim slici izvanjskim uzorom, već sâmo predstavlja normativni uzor. Privid slikom prikazanog preobražava se u osobiti vid zbilje. No, taj vid, ta odlika, da bi bila uzornom, ne može biti puki atribut. Da bi bila samobitnom, ne može biti aspekt ičeg izvan sebe. Što je, dakle, to po čemu sliku možemo poimati kao samobitnu pojavu? To može biti samo ono što po sebi nije vid čega drugoga, što je neovisno o bilo kojem aspektu, što je samodostatno i nedjeljivo. To nešto običavamo nazivati cjelinom.

„Biti odista“, u slikarstvu bi stoga značilo „ostvariti sliku kao cjelinu“. Temeljno svojstvo cjeline je cjelovitost; stoga je cjelovitost slike imperativ koji držimo bitnim preduvjetom slike kao utopijske tvorevine. No, budući da ta distinkcija koju predlažemo ima prevladavajuću ulogu u razumijevanju utopijske naravi slike, važno je osvijetliti pojmovne nijanse i sadržajne implikacije koje iz toga proizlaze. Cjelovitost kao predikat ne može biti puki atribut zbilje u kojoj sudjelujemo, pa tako niti atribut slike, budući da cjelovitost po sebi ne može biti atributom. Strogo gledajući (gledajući dakle s kategorijalnog vidika), cjelovitost nije ono što se čemu pririče, već upravo ono što uvjetuje svako priricanje, uvjet svakog priroka, predikata, odnosno kategorije. ${ }^{9}$ Kao 8 Vidi njegovih dvanaest prijedloga za novu akademiju (Rajnhart, 1975).

9 Priricati znači pripisivati. Iz toga glagola izvodi se imenica prirok, što doslovce znači predikat. Predicirati znači nekome ili nečemu nešto prireći, tj. o nekome ili nečemu reći da je ovakvo ili onakvo. Upravo onako kako predikat u rečenici pririče subjektu neku radnju ili stanje. $U$ isti kontekst pripada 
što gramatička funkcija predikata ne postoji izvan cjeline rečenice, tako i kategorije kao temeljni priroci koji se čemu pririču ne postoje izvan cjeline jezika koji kao sustav mišljenja omogućuje spoznavanje. Cjelina rečenice mjesto je funkcija pojedinačnih gramatičkih sastavnica i smisla koji one iskazuju; cjelina jezika vrijednosna je zasada koja omogućuje/uvjetuje tvorbu temeljnih kategorija kao spoznajnog oruđa. Ta pretpostavka nije proizvoljna. Ona je predmet značajnog filozofskog prijepora oko utemeljenja Aristotelovih (Aristotel) kategorija. Ovdje nismo u prilici prikazati ga ni u naznakama. Dostaje nam tek ukazati na osnovnu premisu: grčki jezik predstavlja ograničenje sustava aristotelovskih kategorija. Ta tvrdnja hoće reći da je „opozicija jezika spram mišljenja nemoguća“ (Derida; Derrida, 2012: 309). Deset Aristotelovih kategorija koje on pririče bivstvu proizlazi iz temeljnih kategorija jezika, a ne iz rasuđivanja koje bi bilo apsolutno. Ta jezička kritika metafizike uma/duha zastupa tezu da ono što može biti mišljeno na stanoviti način proizlazi iz onoga što može biti kazano. Riječima Emila Benvenista (Émile Benveniste), „Ono što nam Aristotel nudi kao popis općih i trajnih uvjeta samo [je] pojmovna projekcija nekog danog jezičnog stanja“ (Benvenist, citirano u Derida, 2012: 318). To ne znači da jezik onemogućuje samostalnu djelatnost duha, već da je mišljenje neodvojivo od jezične sposobnosti, ,jer je jezik značenjem oblikovana struktura, a misliti znači baratati znakovima jezika" (Benvenist, citirano u Derida, 2012: 320). Stoga: „Upravo ono što može biti kazano delimitira i organizira ono što može biti mišljeno" (Derida, 2012: 317).

Bitni zaključak koji proizlazi iz navedenih premisa jest poimanje slike kao djela kojega cjelovitost nije nešto samo po sebi dano. Drugim riječima, cjelovitost nije samorazumljivi atribut. Kao kategorija, ona nije supstancijalna datost, nije supstancija svake slike; cjelovitost se slici pripisuje tek kao svojstvo što je rezultat „nekog danog stanja“. Što čini dano stanje neke slike? To nije lako utvrditi, budući da je slika vrlo složena pojava koja pokriva različite kategorijalne klase. Te se klase križaju s beskonačnim nizom pojedinačnih slikarskih tvorevina, što u bitnome otežava potragu za nekom pragmatičnom formulom. No, to nas ne priječi u mogućnosti da svaku pojedinačnu sliku prepoznamo kao cjelovitu. Ne priječi nas da intuiramo njenu cjelovitost, odnosno da na podlozi konkretnog slikarskog primjera prepoznamo kvalitetu danog stanja. Svako stanje ima pripadajuću mu strukturu, pa tako cjelovitost kao pojmovnu projekciju možemo u slici poimati kao likovnu strukturu, kao svezu materijalnih i perceptivnih sastavnica. Ta je sveza po svojoj naravi odnosna, a ne supstancijalna. Zato ćemo cjelovitost djela prepoznati tamo gdje smo u prilici zamijetiti odnosni poredak unutar date strukture.

i riječ kategorija onako kako ju je upotrebljavao Aristotel. To je imenica izvedena iz grčkog glagola kategorein, što znači optužiti; a kad se nekoga optužuje, onda mu se pririče da je učinio ovo ili ono. Utoliko je i kategorija prirok, odnoso predikat. Razlika je samo u tome koristimo li grecizam (kategorija), latinizam (predikat) ili riječ slavenskog porijekla (prirok) - značenje je isto. 


\section{Koherencija, podudarnost, imitacija}

Sliku možemo shvatiti kao pojavu koja imperativ cjeline dohvaća unutar datosti vlastite strukture. Na ovome mjestu, međutim, morati ćemo uvažiti onaj aspekt cjeline slike koji nije moguće zahvatiti unutar okvira jezičnih analogija. O čemu je riječ? Da bismo to razumijeli, promotrimo načas odliku koju možemo pridružiti fenomenu cjeline. Cjelinu uobičavamo poimati kao strukturu čiji dijelovi nisu tek zbir, nego su uzajamno nedjeljivo povezani. Teorija geštalta taj uvid iskazuje tvrdnjom da je cjelina više od zbira njenih sastavnica. To će reći da cjelinu nije moguće objasniti značajkama pojedinih sastavnica, odnosno njihovim zbrajanjem. Cjelina izmiče pokušajima da je se definira objektivnim, mjerljivim aršinom; neuhvatljiva je sa stanovišta formalne analize, iako su te iste analize u mogućnosti registrirati pojedinačne odnose između formativnih čimbenika. ${ }^{10}$ Ovdje ćemo, međutim, spomenuti tek osnovnu pretpostavku koju možemo evidentirati kao manifestaciju nedjeljive povezanosti sastavnica cjeline. Zovemo je koherencijom, a taj pojam razumijevamo kao snagu koja spreže, objedinjuje, koja se očituje dosljednošću, odsutnošću proturječja.

Riječju: koherencija unutar slike ono je na temelju čega sliku možemo doživjeti uvjerljivom, vjerodostojnom i konačnom. ${ }^{11}$ Kvaliteta koherencije svim formalnim i događajnim sastavnicama pruža vjerodostojnost neopozivog. „Upravo tako“ najveći je kompliment koji možemo pridružiti nekoj umjetnini kao ostvarenom djelu; to je evidencija neopozivog učešća u ideji i realizaciji cjeline. To je možda i najosnovniji dojam koji prati naš doživljaj neke umjetnine. Čitajući, slušajući, gledajući, mi ustvrđujemo: ta knjiga je uvjerljiva, ili pak ta skladba, taj film, nisu. No, želimo li u umjetnini činjenično evidentirati aspekt uvjerljivosti, nismo to u mogućnosti. Kažemo tek: ima odnosno posjeduje „ono nešto“. Nastojimo li međutim na djelu potvrditi dojam neuvjerljivosti, tada bez poteškoće ukazujemo na manjkavosti i nedosljednosti. Zbog čega je tako? Upravo zbog toga što neuvjerljivim doživljavamo djelo koje nije ostvareno kako cjelina, djelo kojega sastavnice možemo zasebno motriti i analizirati, budući da nisu međusobno spregnute logikom cjeline. U tome se nalazi temeljno proturječje slike kao cjeline. Kao cjelina slika je uvjerljiva, dakle lišena proturječja. No, želimo li evidentirati koherenciju kao pojavu lišenu proturječja, bivamo sami lišeni sredstva koje bi tu evidenciju moglo izvršiti. Lišenost proturječja unutar neke slike u jeziku možemo samo iskazati nizanjem proturječja.

Rekli smo da je cjelina rečenice mjesto funkcija pojedinačnih gramatičkih sastavnica i smisla koji one iskazuju. Neuvjerljivu rečenicu „ti ne znala što goforila“

10 Misli se na geometrijsku, strukturalnu analizu, koju ovdje nismo u moguænosti demonstrirati.

11 To se dakako odnosi i na one slike (poetike) koje svoj izržajni zamašnjak utemeljuju na ideji nedosljednosti, na disharmoniji. Tada imperativ djela zahtjeva dosljednost u nedosljednosti, red u neredu - ili radije: prevlast odabranog naèela na uštrb drugih. 
možemo učiniti uvjerljivom i smislenom ako ispravimo gramatičke i tipografske pogrješke. No, kako evidentirati uvjerljivost rečenice poput: ,Jezik prebire svoju prošlost po dnu unutarnjeg otpada“ (Noel; Noël, 2010: 84), ili pak: „Prašina jedne prisutnosti polako kiši u protusvjetlu“(Noel, 2010: 87)? Gramatička ispravnost tu nije jamstvo ni nosilac uvjerljivosti, kao ni rečeničnog smisla. Uvjerljivost tih rečenica uvjetovana je horizontom njihove cjeline. Mogli bismo kazati da nas uvjerava uočena podudarnost, preciznost pojmovnog spajanja. Ali, time samo otvaramo pandorinu kutiju referencija koje obzor rečenice proširuje unedogled. Kritička interpretacija navedenih rečenica to potvrđuje: „Ono što Bernar (Bernard) Noel svaki puta traži upravo je podudarnost, točnost spajanja. Tu točnost treba shvatiti u dvostrukom smislu, estetskom, naravno, ali prije svega etičkom: kako pisati a da riječ bude istinita u svijetu koji neprestano pervertira jezik?“" (Ansen; Ancent, citirano u Noel, 2010: 6). Smisao se tu sagledava u perspektivi cjeline; no ovaj put je to cjelina koja nadilazi rečenicu, to jest „cjelina“ koja je „djelo.“ To nije perspektiva gramatičke i semantičke podudarnosti, već perspektiva analogije kao etičkog ideala. Pa i rečenice/stihovi koje smo naveli analogni su slikama, cjelinom kojih se bavimo i koju cjelinu sričemu s poteškoćom. Dakle, prema analogiji koja nastoji utemeljiti valjani utopijski prikaz, slika je stvarnost čija kvaliteta cjeline može imati analogan odnos spram zbilje. Zbilju tu dakako shvaćamo kao stvarnost lišenu pervertiranosti, izvrnuća, kvarljivosti. ${ }^{12}$

Zbilju kao stanje slike promišljamo kao koherenciju unutar zadane strukture. Zbilju kao stanje svijeta također možemo poimati (pretpostavljati) kao koherenciju unutar njegove strukture. Tako poimana koherencija ustvari je utopijski projekt. Utopijski, stoga što stvarnost koja nas okružuje ne podražava obrazac koherencije. Stoga se zamisao koherencije izdiže na višu potenciju, na potenciju zbilje. Zbiljsko bi stoga bilo ono što unutar sagledane, nama dostupne stvarnosti (ne „slike svijeta“ već svijeta „kao takvog“), omogućuje uvid u njenu koherenciju. Kada je riječ o reciprocitetu dvaju utopijskih projekata (svijeta i slike), problem leži u tomu što je strukturu slike moguće sagledati (u doslovnom, ne u prenesenom smislu), a strukturu svijeta nije (ni u doslovnom, niti u prenesenom smislu). Zbilju svijeta ne zamijećujemo u eventualnoj ukupnosti svega što nju kao takvu može sačinjavati. To kao mogućnost premašuje naše uobičajene spoznajne dosege. Nepreglednost svijeta kao cjeline ne dopušta pronicanje njegove strukture. Preglednost slike, s druge strane, dopušta mogućnost sagledivosti njene strukture.

Mogli bismo kazati da zbilju prepoznajemo po mjestimičnim uzorcima koherencije koji nagovještaju mjeru cjeline. No, pokušaj potvrde tog uvida premašuje

12 Dužni smo podsjetiti na uvriježeno razlikovanje pojmova stvarnosti i zbilje. Stvarnost je ukupnost pojavnog u svijetu koji nas okružuje; zbilja ukljuèuje i sve ono što nadilazi sferu materijalnog, kao što su to ideje, stanja, itd. Pridjev zbiljsko odnosi se pak na ono nepatvoreno, istinsko, svojstvo kojim slika iskazuje zbilju. 
naše sposobnosti i zato se svaki pokušaj potvrde razotkriva kao utopijski projekt. Kada je riječ o slici, koherenciju kao jamstvo cjeline u stanovitoj mjeri možemo verificirati. Možemo naime izložiti one aspekte slike koji ju čine „dobro ugođenim djelom“. Tako sačinjena slikarska djela nisu puke podražavajuće predočbe. One jesu svojevrsne ,imitacije“, ali imitacije koje ne podražavaju izvanjsku stvarnost, već ono slici navlastito. Pri tomu imitativno nije ono što je čemu nalik, već princip podražavanja istog načela koje se manifestira u najrazličitijim slikovnim obrascima. Riječ je o načelu samosličnosti, samozrcaljenja, načelu koje matematičke znanosti poznaju pod nazivom rekurzija. ${ }^{13}$ Princip samozrcaljenja princip je totalnog odjekivanja unutar strukture slike, pri čemu se likovne sastavnice preklapaju s ishodištem vlastite cjeline.

U tom odjekivanju bez ostatka neizrecivim možemo označiti ono mjesto koje za nas na neobičan način ostaje nevidljivo, nedohvatno, a koje generira sva ostala mjesta i njihove odnose u nekoj slici. S obzirom na činjenicu rekurzije koju je moguće formalno opisati, topos neizrecivog nije puka oblikovna činjenica. On je ujedno onaj vid djela koji uvjetuje raspored oblika, odnosne pikturalnih sastavnica, a da sam nije uvjetovan; princip koji određuje konstitutivne sastavnice slike, a da sam nije ničime određen. To prazno, dakle, nazivamo mjestom neizrecivog, stoga što taj princip ne možemo svesti na jednoznačnu, pozitivnu činjenicu. Pozitivno možemo mjeriti tragove njegove prisutnosti u dispoziciji oblikâ unutar slike, u rasporedu silnica koje reguliraju formativne i perceptivne snage. No, sâmo generativno načelo izmiče opažaju; ono je mjesto na koje ne možemo položiti pogled, mjesto koje - opet paradoksalno - ostaje skriveno upravo očitošću vidljivih sastavnica slike.

Stoga, kada rabimo pojam lijepoga pri govoru o slici, to činimo neovisno o uvriježenim estetskim konotacijama tog pojma. Lijepo držimo sinonimom za odliku koja u nama pobuđuje privlačnost nedohvatnog. Nedohvatnog kao faktora koji pokreće našu pažnju, koji je zamašnjak likovnog zbivanja, koji uvijek iznova nadražuje našu vizualnu glad. Sintagma estetički beskraj što ju je skovao Pol Valeri (Paul Valéry) ponajbolje oslikava fenomen koji nastojimo sagledati. Razlikujući skup efekata s konačnom težnjom i skup efekata s beskonačnom težnjom, on upućuje na dvije vrste opažanja, odnosno dojmova koji vladaju našim postupcima. Tražeći prikladan primjer, u prvi skup (koji pridružuje poretku praktičnih stvari) on ubraja osjet gladi. Na poticaj gladi pojedinac konzumiranjem hrane nastoji poništiti taj osjet. Uminuće gladi je konačno, sve dok ne nastupi naredni poticaj. U drugi skup Valeri ubraja nasladu; ukoliko je hrana 'slatka', naslada će nastojati osjet užitka produžiti u beskraj. „Glad nas prisiljava da skratimo jedno osjećanje, a naslada da razvijemo jedno drugo."(Valeri, 1980: 351-353) Ta analogija precizno prikazuje način na koji na nas djeluju slikarska djela.

13 Rekurzija je proces ponavljanja objekata ili slika na samoslièan naèin. Termin koji izvorno dolazi iz matematike i raèunarstva u hrvatsku je likovnu teoriju uveo Vladimir Rismondo u okviru doktorske disertacije (Rismondo, 2010). 
Vizualna glad koju u nama slike pobuđuju nikada ne može do kraja biti utoljenom. Slika je sračunata upravo zato da bude čulna (ali i duhovna) naslada, da našu pažnju održi budnom i prisutnom bez ostatka. Slika je sa svog strukturalnog stanovišta instrument koji za svoju svrhu ima upravo poticanje i održavanje stanja budnosti, stanja prijemčivosti. Mehanizam kojim taj složeni instrument na nas djeluje jest samoobnavljajući; jednom kada je slika zgotovljena, ona neprekidno obnavlja svoj nagovor - ponudu kojoj ne ističe rok trajanja. Slike koje potiču na tu samoobnavljajuću čežnju, slike su koje ujedno u nama izazivaju spomenuti afekt neispunjenog, osujećenog. U naravi naslade i jest da ne može biti nikada u potpunosti konzumiranom. Slikama nikada do kraja ne možemo utoliti našu egzistencijalnu čežnju.

Ta nas činjenica dubinski pogađa, a pogođenost lijepim nitko nije lapidarnije i dojmljivije izrazio od Simon Vel (Simone Weil). Stoga ćemo navodom njene misli zatvoriti ovaj ekskurs o neizrecivoj naravi slikarskog djela, te tvarne utvare koja nas fascinira i zavodi, koja nam u konačnici uvijek ostaje u svojoj bîti zagonetnom.

„Željeli bismo doći iza ljepote, ali ona je samo površina. [...] Ona je sfinga, zagonetna tajna koja nas bolno uzbuđuje.“(Vel, 2010: 153)

\section{LITERATURA:}

1. Adorno, Theodor W. 1979.Estetička teorija. Beograd: Nolit. Citirano u: Protić, Miodrag B. "Oblik I vreme". Beograd: Nolit.

2. Ancent, Jacques. 2010. Citirano u: Kramer, Martina. „Predgovor“; u: Noël, Bernard. Ostatak puta, Zagreb: Litteris.

3. Benveniste, Émile. 1958. Kategorije mišljenja i kategorije jezika. Preuzeto u: Problèmes de linguistique générale. Gallimard, Paris 1966. Citirano u: Derrida, Jacques. 2012. „Nadopuna kopule“; u Europski glasnik ,Godište XVII., br. 17, Zagreb: Hrvatsko društvo pisaca.

4. Blanchot, Maurice. 2015. Književni prostor. Zagreb: Litteris.

5. Derrida, Jacques. 1988. Istina u slikarstvu. Sarajevo: Svjetlost.

6. Derrida, Jacques. 2012. „Nadopuna kopule“; u Europski glasnik ,Godište XVII., br. 17, Zagreb: Hrvatsko društvo pisaca.

7. Noël, Bernard. 2010. Ostatak puta, Zagreb: Litteris.

8. Poe, Edgar Allan. 1986. „Filozofija kompozicije“; u: Edgar Allan Poe, Djela, III. Zagreb: Nakladni zavod Matice hrvatske.

9. Rainhardt, Ad. 1975. Art-as-Art. The Selected Writings of Ad Reinhardt. New York: The Viking Press.

10. Rismondo, Vladimir. 2010. Prostor teksta - prostor slike. Sveučilište J. J. Strossmayera u Osijeku.

11. Stravinsky, Igor. 1975. An Autobiography. Calder and Boyars ed.

12. Valeri, Pol. 1980. Pesničko iskustvo. Beograd: Prosveta. 
13. Weil, Simone. 2010. Iščekivanje Boga. Zagreb: Litteris.

14. Yourcenar, Marguerite. 1999. „Kako se spasio Wang-Fo“; u: Orijentalne priče, Zagreb: Ceres.

\section{Topos of Inexpressible: Contribution to Fundamental Assumptions Underlying the Painting-Language Relationship}

Abstract: The paper analyses some of the fundamental assumptions about understanding the painter's work. The first one is the physical separation of the artwork and the viewer. In its perceptional sense it makes the approach to the painting more difficult, but in its cognitive sense it makes it easy. The separation causes us to feel fascination, which in turn is projected into the painting, which, consequently, becomes the object of our yearning. From the aesthetical point of view, the result of this projection is a specific aspect of the beautiful, the aspect which possesses a utopian potential. Utopia as Outopos (meaning 'no place' or 'nowhere') is another term for the feature in the painting we can refer to as inexpressible. Utopia is not an iconographic factor, but an ontological characteristic of the painting - the painting is always unreachable, inaccessible, since it is merely a (material) occurrence. Its identity is evident in the phenomenon of entirety. However, the phenomenon of entirety in the picture is evident as a coherence, congruence and mimicry. Nevertheless, it is always cognitively elusive, which makes the painting an exciting and mysterious occurrence that occupies our attention, always re-evoking cognitive yearning.

Keywords: painting, fascination, utopia, beautiful, entirety 